\title{
En ung kvinne med slanke hender
}

\author{
En ung kvinne utviklet fra slutten av tenårene gradvis økende atrofi \\ og svekkelse av de små håndmusklene. Den øvrige muskulaturen var \\ upåvirket. Grundig utredning og litteratursøk avslørte etter hvert en \\ svært sjelden diagnose.
}

En kvinne $i$ begynnelsen av 20-årene ble henvist til nevrologisk undersøkelse grunnet langsomt progredierende atrofi av de små håndmusklene og tiltakende svekkelse $i$ venstre og etter hvert også høyre hånd. Symptomene debuterte i slutten av tenårene.

Kvinnen hadde alltid vært frisk, og det var ingen kjente nevrologiske sykdommer i slekten. Hun beskrev nedsatt finmotorikk og vanskeligheter med å skrive fordi hun hadde dårlig grep om pennen. Tilstanden var ikke ledsaget av smerter eller sensibilitetsforstyrrelser. Hun hadde ikke observert tegn til funksjonssvikt i proksimal muskulatur i armene eller i underekstremitetene.

Ved nevrologisk undersøkelse ble det bemerket markert atrofi og pareser i de små håndmusklene innervert av n. ulnaris og n. medianus, spesielt thenar, hypothenar, lumbrikalene og interossene (fig 1, fig 2). Det var ingen sikker atrofi eller pareser $i$ underarmsmuskulaturen. Hun hadde god kraft for fleksjon og ekstensjon $i$ håndleddet, slik at mer proksimalt beliggende medianus- og ulnarisinnervert muskulatur samt radialisinnervert muskulatur ble vurdert som intakt. Det var ingen synlig atrofi eller pareser ioverarmens eller skulderbuens muskulatur, og det var normal muskelfylde med god symmetrisk kraft i begge underekstremitetene.

Tempoet for de finere fingerbevegelser var nedsatt, svarende til paresene, for øvrig normalt. Det ble ikke observert fascikulasjoner. Koordineringsprøvene var upåfallende. Pasienten anga normal sensibilitet for alle sansekvaliteter. Refleksene var middels livlige og symmetriske, plantarrefleksene nedadvendte. Hun hadde ingen smerter $i$ nakken, det var fri bevegelighet i cervikalcolumna og negativt Lhermittes tegn. Hjernenerveundersøkelse og pasientens mentale status var uten anmerkning.

På grunn av relativt langsomt progredierende symptomutvikling vurderte vi en nevrodegenerativ sykdom, som spinal muskelatrofi, som en nærliggende diagnose. Det var imidlertid uvanlig at kun de små håndmusklene var affisert.

Andre mulige diagnoser vi initialt tok med $i$ betraktningen var benigne former for motornevronsykdommer, strukturelle lesjoner i cer- vikalcolumna, en form for motorisk nevropati og nevrogent thoraxapertursyndrom (neurogenic thoracic outlet syndrome). Muligheten for en atypisk form for pleksusnevritt ble også vurdert, selv om vi anså denne diagnosen som mindre sannsynlig fordi det ikke var smerte. Det kliniske bildet var nokså uvanlig - med funn som tydet på en isolert affeksjon av nedre motornevron i et avgrenset medullært nivå fra C6 til TH1.

Det ble iverksatt en bred utredning med blodprøver, MR-undersøkelse av medulla og caput og spinalvæskeundersøkelse. Klinisk nevrofysiologisk undersøkelse ble utført med nevrografi fra begge overekstremiteter og høyre underekstremitet samt elektromyografi (EMG) fra høyre sides ekstremiteter.

Blodprøver, inklusive kreatinkinase (CK), som ble kontrollert flere ganger, var helt normale. Gangliosidantistoffer (GM1-antistoffer) var negative. Det var normale funn ved spinalvæskeundersøkelse.

MR av ryggmargen viste markert atrofi fra nivå C4 til Th2 og to langsgående symmetriske T2-vektede høysignallesjoner fra nivå C2 til Th2 (fig 3, fig 4), lokalisert til området for anteriore horn i medulla. Forandringene ble ikke oppfattet å være forenlig med syringomyeli, demyeliniserende plakk, tumor eller transvers myelitt. Det var normale funn ved MR caput.

I overekstremitetene var sensorisk og motorisk nerveledningshastighet for n. medianus og n. ulnaris innenfor normalområdet. Det ble målt lave motoriske svaramplituder for $n$. medianus på venstre side og begge $n$. ulnaris, $i$ størrelsesorden 0,7-2,5 mV (normalt > 4-5 $m V$, men atrofi vil innvirke på amplitudestørrelsen). F-responsene var forsinket $i$ begge n. ulnaris, ca. 30-35 ms (normalt < $28 \mathrm{~ms}$ ), vanskelig påvisbare for høyre $n$. medianus og $i$ øvre del av normalområdet for venstre $n$. medianus. Nevrografisk undersøkelse, inklusive F-responser $i$ underekstremiteten, var normal.

Antall nålestikk ved EMG-undersøkelsen ble begrenset, da pasienten var redd for stikk, men elektromyografi fra høyre sides ekstremiteter avdekket kronisk perifernevrogene forandringer $i \mathrm{~m}$. abductor digiti minimi og $i$ ekstensorgruppen, mens det $i$ første dorsale

\author{
Karl-Friedrich Amthor \\ karl-friedrich.amthor@vestreviken.no \\ Nevrologisk avdeling \\ Tom Pedersen* \\ Radiologisk avdeling \\ Drammen sykehus
}

\section{Ketil Berg Olsen*}

Klinisk nevrofysiologisk laboratorium Oslo universitetssykehus, Rikshospitalet

* Nåværende arbeidssted:

T. Pedersen, Unilabs Røntgen Drammen

K.B. Olsen, Klinisk nevrofysiologisk laboratorium, Sykehuset Østfold Fredrikstad

ㄴ. Engelsk oversettelse på www.tidsskriftet.no 
interossei ble påvist subakutte perifernevrogene forandringer med lett denervasjonsaktivitet. Det var ingen tegn til fascikulasjoner i de undersøkte musklene. EMG-funn i proksimal muskulatur i overekstremiteten og $i$ underekstremiteten var normale.

Pasienten hadde en uvanlig klinisk tilstand og meget uvanlige MR-forandringer i ryggmargen. Det ble konferert med flere nevroradiologer, uten at man kom nærmere en etiologisk diagnose. Våre diagnostiske overveielser gikk fortsatt mest i retning av en form for distal spinal muskelatrofi. Funnene ved nevrofysiologisk undersøkelse avdekket imidlertid ikke de klassiske forandringer som forventes ved spinale muskelatrofier, da det som oftest er mest forandringer i proksimal muskulatur og i underekstremiteter. Hos vår pasient var det mest forandringer distalt i overekstremitetene. Forsinket F-respons med normale ledningshastigheter i ekstremiteten tydet på en proksimal, rotnær nerveaffeksjon.

Det var ingen nevrofysiologiske holdepunkter for amyotrofisk lateral sklerose, heller ingen funn som tydet på samtidig denervasjon og reinnervasjon i de fleste undersøkte muskler, og ingen spontanaktivitet. Ikke-reduserte amplituder proksimalt sammenliknet med distalt og negative GM1antistoffer talte imot multifokal motorisk nevropati med konduksjonsblokk. Med normale distale latenstider for $\mathrm{n}$. ulnaris og $\mathrm{n}$. medianus hadde man heller ikke holdepunkter for patologiske forhold i Guyons kanal eller canalis carpi. Det var normal kreatinkinase og ingen typiske EMG-forandringer som kunne indikere myopati.

En annen mulig årsak til atrofi og pareser av de små håndmusklene er nevrogent thoraxapertursyndrom. Tilstanden skyldes kompresjon av plexus brachialis, ofte av en halsribbe, og debuterer som regel med smerter eller parestesier ulnart $\mathrm{i}$ armen. Hos vår pasient var det ikke påvist anomalier i cervikalcolumna. Hun hadde heller aldri hatt smerter eller parestesier, slik at denne differensialdiagnosen også ble ansett som lite sannsynlig.

Etter et internettsøk fant vi en artikkel fra 1978 der O'Sullivan \& McLeod beskrev seks pasienter med kronisk distal spinal muskelatrofi som affiserte hendene (1). Disse pasientene hadde 10-30 års sykehistorie med langsomt progredierende muskelsvinn og svekkelse av de små håndmusklene. De kliniske funn var begrenset til hendene hos alle pasientene.

Ifølge forfatterne var det ingen kliniske eller radiologiske holdepunkter for perifer eller proksimal nerverotaffeksjon eller sykdom i det sentrale nervesystemet. Nevrofysiologiske undersøkelser bekreftet at mus-

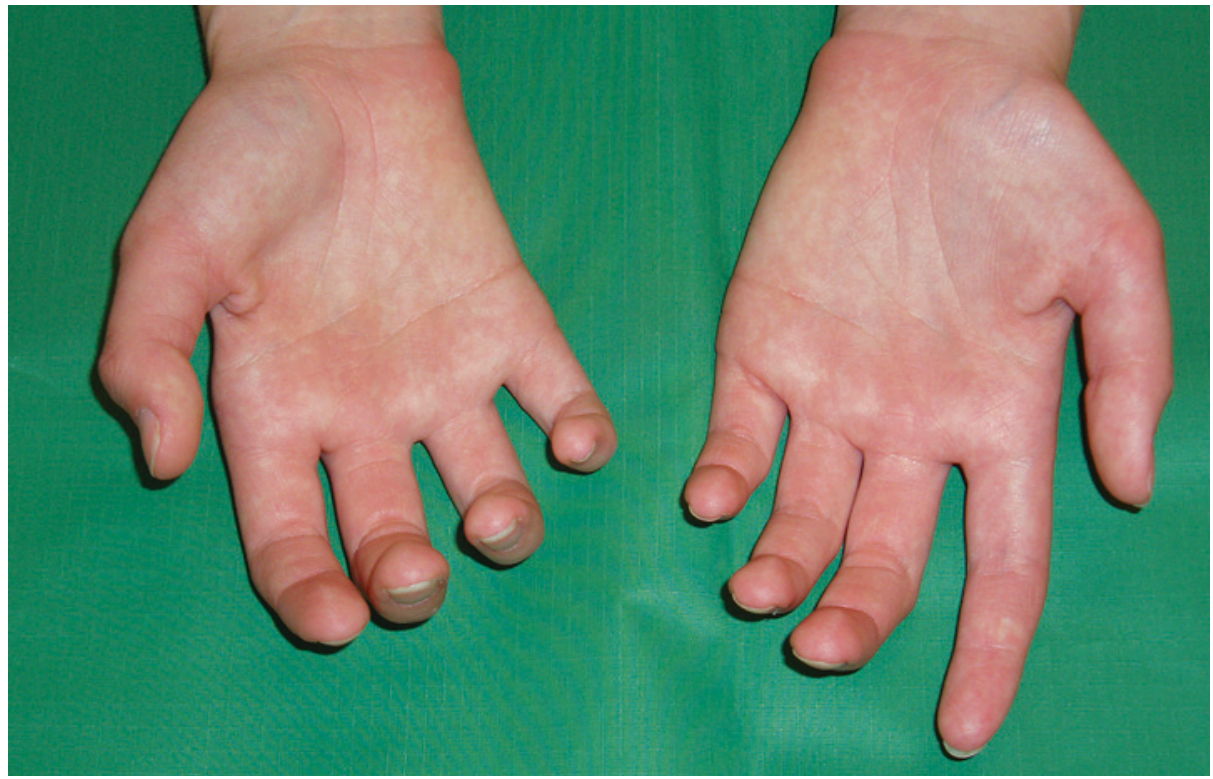

Figur 1 Markert atrofi av de små håndmusklene, palmarsiden

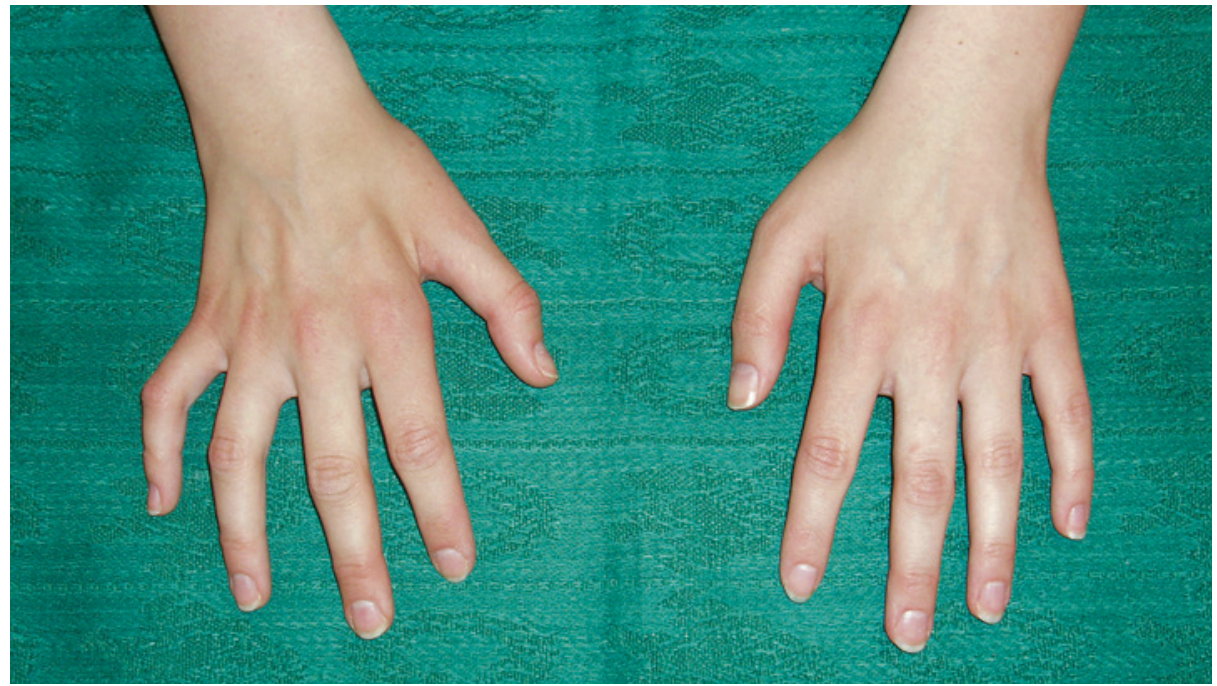

Figur 2 Markert atrofi av de små håndmusklene, volarsiden

kelatrofien var følge av en kronisk partiel denervering. Motoriske og sensoriske nerveledningshastigheter var normale. Cervikal myelografi avdekket ingen patologiske funn. Kliniske, radiologiske og nevrofysiologiske funn ble tolket til å være forenlig med en kronisk degenerering av motoriske forhornceller. Tilstanden er senere blitt kalt O'Sullivan-McLeod-syndromet.

Hos vår pasient har det ikke skjedd noe sikker progrediering av tilstanden på ti år, bedømt ut fra kliniske funn og MR-funn.

\section{Diskusjon}

Spinale muskelatrofier (SMA) er en heterogen sykdomsgruppe som vanligvis debuterer med svakhet i proksimale muskelgrupper som følge av en langsomt progredierende degenerering av det nedre motornevronet. De fleste spinale muskelatrofier er arvelige, men sporadiske tilfeller kan forekomme. Sjeldnere og lokaliserte varianter med affeksjon av distal muskulatur og forholdsvis god prognose er beskrevet $(2,3)$.

Ved andre former for distale spinale muskelatrofier, som SMA-V, er både over- og underekstremiteter affisert. Charcot-MarieTooth type 2D (CMT) er en arvelig polynevropati med en liknende fenotype som SMA-V (4). Hovedforskjellen mellom disse to tilstandene er distalt sensibilitetstap hos pasienter med Charcot-Marie-Tooth type 2D. Begge tilstandene er autosomalt dominant arvelige og derfor lite sannsynlig hos vår pasient. Muligheten for en de novo- 


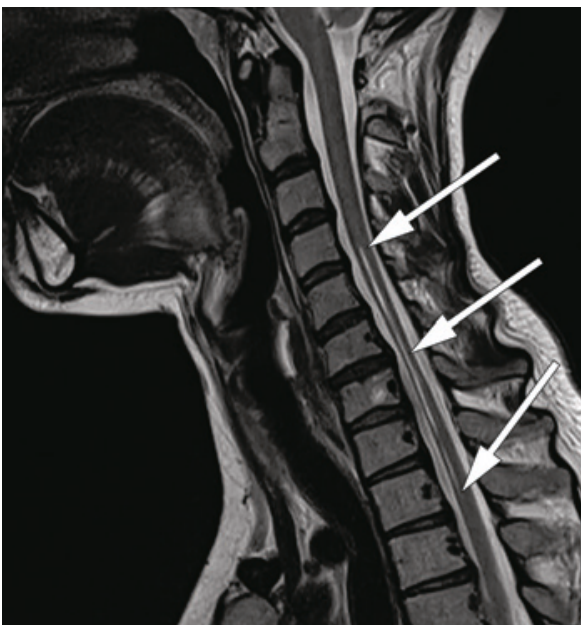

Figur 3 Sagittal T2-vektet cervikal MR med atrofiav medulla fra C6 til Th2 og høysignallesjon fra C4 til Th2

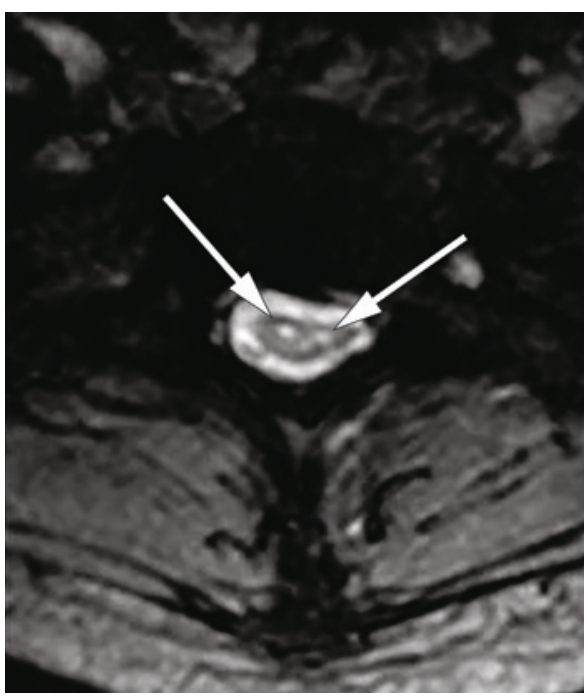

Figur 4 Aksial T2-vektet MR av cervikalmedulla med symmetriske høysignallesjoner lokalisert til området for forhorncellene

mutasjon hos vår pasient er til stede. Anamnestisk var det ikke holdepunkter for en arvelig nevrologisk lidelse.

En tilstand med liknende kliniske manifestasjoner er Hirayamas sykdom. Dette er en benign, ikke-familiær fokal amyotrofi, som typisk affiserer en overekstremitet. Tilstanden rammer oftest unge menn. Det er angitt hyppigere prevalens hos asiater enn hos kaukasiere (5). Bilaterale manifestasjoner av Hirayamas sykdom er beskrevet (6). Noen forfattere mener at disse to tilstandene er identiske (7). Ved O'Sullivan-McLeodsyndromet er de kliniske funnene imidlertid mer avgrenset, med atrofi og pareser av de små håndmusklene, mens Hiaryamas sykom som regel også affiserer under- og overarmsmuskulatur. Derfor betegnes tilstanden også monomelisk amyotrofi.

Etiologien ved Hirayamas sykdom er omdiskutert. Mekanisk deformasjon av cervikal medulla i forbindelse med nakkefleksjon grunnet utilstrekkelig vekst av dura i forhold til ryggsøylen i ungdomsperioden er foreslått som én mulig årsak (8). Det er rapportert fokal atrofi og signalforandringer $\mathrm{i}$ cervikal medulla ved Hirayamas sykdom i to studier $(9,10)$.

Det er publisert flere kasuistikker og noen få MR-studier vedrørende O'SullivanMcLeod-syndromet, men ingen oversiktsartikler. I 1989 publiserte Gaio og medarbeidere (11) en serie med fem pasienter. MR av cervikal- og torakalcolumna ble gjennomført hos fire pasienter med T1- og T2-vektede bilder. På T1-vektet serie ble det beskrevet avflating av medulla fra C5 til Th1 og normale forhold fra $\mathrm{C} 1$ til $\mathrm{C} 4$. Funnet ble tolket som segmental spinal atrofi av medulla. Signalforandringer i medulla ble ikke påvist.

Petiot og medarbeidere (12) publiserte i 2000 en kasuistikk av en 41 år gammel kvinne med O'Sullivan-McLeod-syndromet. Pasienten hadde over en periode på 20 år utviklet en langsomt progredierende asymmetrisk svakhet i begge hender. Det var ingen nevrologiske sykdommer i slekten. MR av cervikalcolumna avdekket symmetriske høysignallesjoner på T2-vektede bilder, svarende til et område av forhorncellene som strakte seg fra nivå C6 til C7. Diameteren av cervikalmedulla ble vurdert som normal.

Etiologien ved O'Sullivan-McLeod-syndromet er ukjent. Antakeligvis dreier det seg om en nevrodegenerativ tilstand. Det er ingen holdepunkter for at tilstanden er arvelig. En liknende patofysiologisk mekanisme som ved Hirayamas sykdom kan tenkes, men er ikke beskrevet i litteraturen. Med bakgrunn i en kasuistikk som viste forbigående bedring av muskelsvekkelsen etter behandling med immunglobulin intravenøst er det blitt drøftet om en immunmediert nevronskade kan være en medvirkende patogenetisk årsak (13).

Bortsett fra denne ene rapporten er det ikke beskrevet noen form for spesifikk behandling. Fordi tilstanden er meget sjelden, vil det neppe være mulig å gjennomføre randomiserte, kontrollerte studier. Prognosen synes å være god.

\section{Konklusjon}

O'Sullivan-McLeod-syndromet er en sjelden form for distal spinal muskelatrofi med forholdsvis god prognose. Diagnosen bygger på kliniske og nevrofysiologiske undersøkelser og karakteristiske MR-forandringer med segmental atrofi i cervikalmedulla og høysignallesjoner i området svarende til fremre motornevron.

\section{Karl-Friedrich Amthor (f.1950)}

er spesialist i nevrologi, dr.med. og seksjonsoverlege.

Forfatter har fylt ut ICMJE-skjemaet og oppgir følgende interessekonflikter: Han har mottatt foredragshonorar fra Boehringer Ingelheim, Glaxo, Bayer og Høgskolen i Buskerud.

\section{Tom Pedersen (f. 1952)}

er spesialist i radiologi og medisinsk ansvarlig overlege ved Unilabs Drammen.

Forfatter har fylt ut ICMJE-skjemaet og oppgir ingen interessekonflikter.

\section{Ketil Berg Olsen (f. 1970)}

er spesialist i nevrologi og klinisk nevrofysiologi og seksjonsoverlege ved Klinisk nevrofysiologisk laboratorium, Sykehuset Østfold.

Forfatter har fylt ut ICMJE-skjemaet og oppgir ingen interessekonflikter.

\section{Litteratur}

1. O'Sullivan DJ, McLeod JG. Distal chronic spinal muscular atrophy involving the hands. J Neurol Neurosurg Psychiatry 1978: 41:653-8.

2. Meadows JC, Marsden CD. A distal form of chronic spinal muscular atrophy. Neurology 1969; 19: $53-8$

3. Harding AE, Bradbury PG, Murray NM. Chronic asymmetrical spinal muscular atrophy. J Neurol Sci 1983; 59: 69-83

4. Antonellis A, Ellsworth RE, Sambuughin $\mathrm{N}$ et al. Glycyl tRNA synthetase mutations in CharcotMarie-Tooth disease type 2D and distal spinal muscular atrophy type V. Am J Hum Genet 2003; 72: $1293-9$

5. Hirayama K, Tsubaki T, Toyokura Y et al. Juvenile muscular atrophy of unilateral upper extremity. Neurology 1963: 13: 373-80.

6. Pradhan S. Bilaterally symmetric form of Hirayama disease. Neurology 2009; 72: 2083-9.

7. Ghadiri-Sani M, Dougan C, Lecky B. Slowly progressive upper limb weakness: Two cases of Hirayama disease and review of literature. J Neurol Neurosurg Psychiatry 2013; 84: e2.

8. Hirayama K, Tokumaru Y. Cervical dural sac and spinal cord in juvenile muscular atrophy of distal upper extremity. Neurology 2000; 54: 1922-6.

9. Schröder R, Keller E, Flacke $\mathrm{S}$ et al. MRI findings in Hirayama's disease: flexion-induced cervical myelopathy or intrinsic motor neuron disease? J Neurol 1999: 246: 1069-74.

10. Desai JA, Melanson M. Teaching neuroimages: Anterior horn cell hyperintensity in Hirayama disease. Neurology 211; 77: pe73.

11. Gaio JM, Lechevalier B, Hommel M et al. Amyotrophie spinale chronique des membres supérieurs de l?adulte jeune Isyndrome de O'Sullivan et McLeod). Etude en IRM de la moelle cervicale. Rev Neurol (Paris) 1989; 145: 163-8.

12. Petiot $\mathrm{P}$, Gonon V, Froment JC et al. Slowly progressive spinal muscular atrophy of the hands (O'Sullivan-McLeod syndrome): clinical and magnetic resonance imaging presentation. J Neurol 2000; 247: 654-5.

13. Kawano Y, Nagara Y, Murai $\mathrm{H}$ et al. Slowly progressive distal muscular atrophy of the bilateral upper limbs (0'Sullivan-McLeod syndrome) partially alleviated by intravenous immunoglobulin therapy. Intern Med 2007; 46: 515-8. 